\title{
Pengembangan LKS Pemecahan Masalah Matematika Bilingual Berdasarkan Strategi Metakognitif untuk SMP Kelas VII
}

\author{
Hasbullah $^{1}$, Yogi Wiratomo ${ }^{2}$, Eva Yuni Rahmawati ${ }^{3}$ \\ 1,2,3 Program Studi Pendidikan Matematika, Universitas Indraprasta PGRI Jakarta, \\ ${ }^{1}$ hasbule@gmail.com, ${ }^{2}$ yogiwiratomo@ymail.com, ${ }^{3}$ everez29@gmail.com
}

\section{INFO ARTIKEL}

Riwayat Artikel:

Diterima: 13-02-2018

Disetujui: 16-03-2018

\section{Kata Kunci: \\ Lembar Kerja Siswa, \\ Matematika, \\ Strategi Pembelajaran, \\ Metakognitif, \\ Pemecahan masalah}

\section{ABSTRAK}

Abstrak: Penelitian ini bertujuan untuk mengembangkan Lembar Kerja Siswa Matematika berdasarkan strategi metakognitif. Metode penelitian ini adalah penelitian pengembangan dengan menggunakan model Dick \& Carey. Proses penelitian ini dilakukan dalam urutan aktivitas sebagai berikut: 1. Melakukan analisis kebutuhan, 2) menentukan tujuan instruksional umum, 3) menentukan peta kompetensi, 4) meninjau karakteristik dan latar belakang peserta didik, 5) menentukan tujuan instruksional yang spesifik, Penilaian, 7) menentukan strategi pembelajaran, 8) menentukan materi pembelajaran, 9) melakukan evaluasi formatif, dan terakhir 10) melaksanakan evaluasi sumatif dan difusi inovasi pembelajaran. Penelitian ini menghasilkan bahan ajar dalam bentuk Lembar Kerja Siswa

\begin{abstract}
This research aims to develop Mathematics Student Worksheet based on Metacognitive Strategy. This research method is research development by using model of Dick \& Carey. The process of this research is conducted in order of relevance as follows: 1. analysis results, 2) understanding of general instructional goals, 3) understanding of the map, 4) understanding of the characteristics and background of learners, 5) determination of specific instructional goals, assessment, 7) determination learning strategies, 8) determining learning materials, 9) conducting formative evaluations, and finally 10) implementing summative evaluations and. This study produces teaching materials in the form of Student Worksheet.
\end{abstract}

\section{A. LATAR BELAKANG}

Matematika adalah salah satu mata pelajaran wajib yang diajarkan kepada siswa di setiap jenjang pendidikan, salah satunya di program bilingual tingkat SMP. Matematika dalam program bilingual masih merupakan momok yang menakutkan karena matematika memiliki sifat yang sangat abstrak. Hal ini berdampak pada proses belajar matematika yang selalu mengkhawatirkan dan tidak menarik bagi siswa. Pembelajaran matematika di sekolah menengah pertama Program bilingual harus menjadi kegiatan yang menyenangkan dan melibatkan siswa secara aktif dalam proses pembelajaran, sehingga siswa termotivasi dan tidak merasa bosan dalam belajar matematika. Dengan belajar yang menyenangkan diharapkan untuk mencapai tujuan pembelajaran matematika dalam program Bilingual SMP.

Menurut National Council of Teachers of Mathematics (2000) Pembelajaran matematika memiliki tujuan sebagai berikut: (1) belajar berkomunikasi (komunikasi matematis); (2) belajar akal (penalaran matematis); (3) belajar memecahkan masalah (mathematical problem solving); (4) belajar mengasosiasikan gagasan (koneksi matematis); (5) pembentukan sikap positif terhadap matematika (sikap positif terhadap matematika). Pembelajaran matematika di sebagian besar sekolah masih belum mencapai tujuan, terutama di Sekolah Menengah Pertama Bilingual. Sebagian besar siswa masih mengalami kesulitan belajar matematika, terutama dalam memecahkan masalah yang berkaitan dengan pemecahan masalah. Apalagi siswa yang sudah memiliki jumlah pengetahuan yang dibutuhkan untuk memecahkan masalah matematika, seringkali belum bisa menggunakan pengetahuan tersebut untuk memecahkan masalah atau masalah baru yang belum mengenalnya. Selain itu, siswa belum dikembangkan sikap pembelajaran yang kreatif dan mudah menyerah dalam menghadapi masalah matematika yang pada akhirnya berimplikasi pada rendahnya kemampuan untuk memecahkan masalah.

Banyak faktor yang menyebabkan kurangnya pengetahuan siswa dalam memecahkan masalah matematika. Salah satunya adalah perangkat pembelajaran yang dimiliki oleh guru, terutama bahan ajar. Melalui Peraturan Menteri Pendidikan Nasional (Permendiknas) nomor 41 tahun 2007 
tentang Proses Standar yang antara lain diharapkan guru dapat mengembangkan bahan ajar sebagai salah satu sumber pembelajaran. Dengan bahan ajar, guru dapat mencapai tujuan pembelajaran seperti yang diharapkan sebelumnya.

Salah satu bahan ajar yang perlu diperhatikan guru adalah Lembar Kerja Siswa. LKS. Menurut Trianto (2012) LKS sebagai panduan bagi mahasiswa untuk melakukan investigasi atau pemecahan masalah. LKS berisi kegiatan yang harus dilakukan oleh siswa untuk mencapai indikator pencapaian hasil belajar. Berdasarkan uraian tersebut, LKS dapat digunakan sebagai pedoman bagi siswa untuk secara aktif terlibat dalam kegiatan belajar dan membantu siswa langsung untuk membangun belajar pengetahuan t o memecahkan masalah matematika.

Sebagian besar siswa matematika LKS dalam program Bilingual SMP di Jakarta Selatan yang digunakan siswa hanya dalam memecahkan masalah perhitungan. Padahal LKS belum tentu sesuai dengan tujuan pembelajaran yang ingin dicapai. Apalagi dengan tampilan LKS yang kurang menarik dan gaya bahasa yang sulit dimengerti oleh para siswa. Ini adalah kekurangan LKS yang digunakan sebagai bahan ajar dalam pembelajaran. Saat ini sudah banyak model matematika LKS yang telah dirancang guru. Namun seiring dengan perubahan kurikulum, pengembangan LKS disesuaikan dengan karakteristik siswa dan strategi pengajaran yang dipilih oleh guru. Salah satu strategi guru dapat u se adalah strategi metakognitif.

Strategi metakognitif sebagai salah satu strategi yang dapat membantu guru mengembangkan matematika LKS di program SMP Bilingual di Jakarta Selatan. Guru dapat memodifikasi atau merancang LKS matematika lama dengan mengubah beberapa komponen yang ada. Mengingat bahwa matematika adalah subjek yang menghubungkan beberapa konsep yang saling terkait. Oleh karena itu, perlu untuk pengembangan LKS untuk menciptakan proses pembelajaran yang bermakna dan sesuai dengan ketentuan dan karacteristik siswa.

Pengembangan strategi metakognitif berbasis LKS berbasis matematika dapat memberi kesempatan kepada siswa untuk membangun pengetahuan dengan terlibat dalam aktivitas berpikir aktif. Melalui strategi pembelajaran metakognitif, pemecahan masalah matematis dapat diarahkan untuk mengembangkan ketrampilan siswa seperti: membangun pengetahuan matematika baru, memecahkan masalah dalam berbagai konteks yang berkaitan dengan matematika, menerapkan strategi yang diperlukan, dan merenungkan proses pemecahan masalah secara matematis. Semua kemampuan ini dapat diperoleh jika siswa terbiasa untuk melakukan pemecahan masalah sesuai dengan prosedur yang tepat, sehingga ruang lingkup manfaat yang diperoleh tidak hanya terikat pada satu masalah diselesaikan, tetapi juga menyentuh pada isu-isu lain dan termasuk lebih luas sebagai dampak dari pengetahuan matematika. Lembar Kerja Siswa adalah seperangkat kegiatan yang memberi kesempatan kepada siswa untuk memperluas pemahaman mereka terhadap materi yang dipelajari sesuai dengan tujuan pembelajaran yang akan dicapai. Majid (2012) yaitu berupa lembar kerja yang harus dikerjakan oleh siswa. LKS biasanya berisi instruksi bagi siswa untuk melakukan aktivitas. Ini bertujuan untuk membimbing siswa melakukan aktivitas aktif selama proses pembelajaran. Menurut Trianto (2012), LKS adalah panduan bagi siswa untuk melakukan kegiatan dasar untuk memaksimalkan pemahaman menurut indikator hasil belajar.

Pemahaman serupa dijelaskan oleh Prastowo (2011) yang merupakan bahan cetakan berupa lembaran yang disusun secara sistematis berisi bahan, rangkuman dan instruksi instruksi instruksional yang bertujuan membimbing siswa melakukan kegiatan yang secara aktif mengacu pada kompetensi dasar. Prastowo (2011) memiliki beberapa fungsi dalam kegiatan pembelajaran yang adalah sebagai berikut: 1 . Sebagai bahan pengajaran yang dapat meminimalkan peran pendidik, tetapi lebih memungkinkan peserta didik. 2. Sebagai bahan ajar yang memudahkan peserta didik untuk memahami materi yang disajikan. 3. Sebagai bahan ajar yang ringkas dan tugas yang kaya untuk berlatih. 4. Memfasilitasi pelaksanaan pengajaran kepada peserta didik. Berdasarkan pemaparan di atas, fungsi LKS umumnya sebagai media yang membantu siswa untuk meningkatkan pemahaman mereka tentang materi melalui urutan langkah-langkah yang telah dirancang sebelumnya dan siswa dapat mengekspresikan kemampuan ir dalam memecahkan masalah.

Manfaat penggunaan LKS untuk kegiatan pembelajaran menurut Prastowo (2011) adalah sebagai berikut: 1 . Mengaktifkan siswa dalam proses pembelajaran. 2. Membantu siswa dalam mengembangkan konsep. 3. Latih siswa dalam menemukan dan mengembangkan keterampilan proses. 4. Latih siswa untuk memecahkan masalah dan berpikir kritis. 5. Sebagai pedoman bagi guru dan siswa dalam melaksanakan proses pembelajaran. 6 . Bantu siswa mendapatkan catatan materi yang dipelajari melalui kegiatan belajar. 7. Bantuan siswa menambah informasi tentang konsep belajar melalui kegiatan belajar secara sistematis. Sehingga dapat disimpulkan bahwa LKS merupakan pedoman yang telah disusun sedemikian rupa sehingga memberi kesempatan kepada siswa untuk memperluas pemahaman materi yang menjadi tujuan pembelajaran. Pedoman tersebut berisi kegiatan yang diarahkan dan aktif. Sehingga LKS bisa dijadikan pedoman bagi siswa dalam melakukan kegiatan belajar mengajar. 
Strategi metakognitif berkaitan dengan cara untuk meningkatkan kesadaran tentang proses berpikir dan pembelajaran yang sedang berlangsung. Saat kesadaran ada, seseorang bisa mengendalikan pikirannya. Siswa dapat menggunakan strategi metakognitif dalam pembelajaran meliputi tiga tahap berikut: merancang apa yang ingin mereka pelajari; Pantau pengembangan diri dalam belajar; Dan menilai apa yang dipelajari. strategi Metakognitif dapat digunakan untuk studi apapun bidang studi.

Sprinthall (1992), mengungkapkan strategi metakognisi adalah 1) memberikan umpan balik, 2) memberi siswa catatan pembelajaran dan, 3) mengajari siswa cara menilai mereka. Iskandarwassid dan sunendar mengatakan bahwa strategi metakognisi membuat siswa sadar akan proses membaca dan memecahkan masalah belajar. Siswa akan lebih sadar akan keterampilan yang dibutuhkan untuk memenuhi situasi belajar tertentu dan misalnya penerapan strategi metakognisi ini, setelah membaca cerita pelajar dan membantu siswa menganalisis pertanyaan untuk menentukan proses pemikiran yang dibutuhkan untuk menemukan jawaban (Iskandarwassid dan Sunendar, 2008). Strategi metakognisi membawa peserta didik ke proses yang mereka sebut strategi mental. Dalam mengajarkan proses berpikir, peserta didik perlu melakukan hal berikut: 1) memusatkan perhatian pada peserta didik, 2) menekankan nilai demonstrasi, 3) berbicara dalam percakapan, membuat langkah yang sederhana dan jelas dan 5) membantu pelajar ingat Metakognisi adalah strategi untuk melaksanakan dan monitoring, pemikiran yang melibatkan penalaran dari peserta didik dan berfokus pada penggunaan Kellough penalaran (1994: 266), menunjukkan bahwa kondisi strategi metakognitif peserta didik secara aktif merencanakan, monitoring, evaluasi dalam pembelajaran.

Menurut Preisseisen di Harvest (1997), menjelaskan bahwa metakognisi mencakup empat jenis keterampilan, yaitu: 1) Ketrampilan memecahkan yaitu keterampilan individu dalam menggunakan proses berpikir untuk memecahkan masalah melalui pengumpulan fakta, analisis informasi, penyiapan berbagai solusi. dan Memilih pemecahan masalah yang paling efektif, 2) keterampilan pengambilan keputusan dalam menggunakan proses berpikir untuk memilih keputusan terbaik dari beberapa opsi yang tersedia melalui pengumpulan informasi, perbandingan antara kebaikan dan kekurangan masing-masing alternatif, analisis informasi terbaik dan pengambilan keputusan berdasarkan Alasannya rasional, 3) kemampuan berpikir kritis menggunakan proses pemikirannya untuk menganalisis argumen dan memberikan interpretasi berdasarkan persepsi penalaran logis yang valid, analisis asumsi dan bias argumen dan interpretasi logis, 4) kemampuan berpikir kreatif dari yaitu menggunakan proses berpikir untuk menghasilkan gagasan baru yang konstruktif dan bagus berdasarkan konsep rasional maupun individual persepsi dan intuisi

Berdasarkan konsep di atas dapat disimpulkan bahwa strategi pembelajaran metakognitif adalah strategi yang mengkondisikan peserta didik untuk selalu aktif yang meliputi proses perencanaan, pemantauan, evaluasi kemajuan berfikir dalam pembelajaran.

\section{B. METODE PPENELITIAN}

Penelitian ini merupakan jenis penelitian dan pengembangan. Penelitian ini dilakukan di SMP Bilingual di Jakarta Selatan. Teknik pengumpulan data dalam penelitian ini adalah observasi dan wawancara. Analisis data dalam penelitian ini menggunakan statistik deskriptif. Metode pengembangannya dilakukan dengan menggunakan model pengembangan Dick and Carey. Langkahlangkah dalam penelitian ini adalah (1) Need Assessment, (2) Penentuan Tujuan Instruksional Umum, (3) Menentukan Peta Kompetensi, (4) Melakukan Analisis Karakteristik Peserta didik, (5) Menentukan Tujuan Instruksional Khusus, (6) Alat Penilaian, setelah menetapkan tujuan instruksional khusus, (7) Mengembangkan Strategi Pembelajaran,

\section{HASIL DAN PEMBAHASAN}

Penelitian ini mengembangkan LKS matematika untuk kelas VII SMP berbasis strategi metakognitif, pengembangan ini dimulai dengan analisis kebutuhan. Pada tahap ini ada beberapa analisis yang telah dilakukan yaitu analisis kurikulum, dan analisis kebutuhan siswa. Hasil analisis kurikulum yaitu kurikulum yang digunakan adalah kurikulum tingkat satuan pendidikan (KTSP). Berdasarkan permendiknas no. 22 tahun 2006 tentang mata pelajaran Standar Konten Matematika untuk semua tingkat pendidikan dasar dan menengah menyatakan bahwa tujuan matematika di sekolah adalah agar siswa dapat memahami konsep, menggunakan penalaran, memecahkan masalah termasuk kemampuan untuk memahami masalah, mengkomunikasikan gagasan dan pemikiran sikap menghargai kegunaan matematika dalam kehidupan (BSNP, 2006). Tujuan ini sesuai dengan strategi metakognitif di mana siswa diharapkan memiliki keterampilan untuk memecahkan masalah matematika dalam kehidupan sehari- hari dan menemukan konsep pembelajaran matematika. Selanjutnya, analisis kurikulum dilakukan pada Kompetensi Dasar (KD) dan materi kelas VII SMP.

Analisis kurikulum matematika untuk kelas tujuh SMP adalah tentang kesesuaian material dengan strategi metakognitif. Dari semua KD 
menunjukkan semua dapat diterapkan dalam mengembangkan metakognitif berbasis LKS. Analisis materi juga menghasilkan pemikiran bahwa kebutuhan untuk presentasi strategi metakognitif berbasis LKS.

Sedangkan hasil analisis siswa adalah siswa kelas VII. Menurut teori pembelajaran piaget bahwa siswa yang berusia 11-15 tahun berpikiran lengkap, berpikir proporsional, kemampuan untuk mengatasi hipotesis. Pada usia ini siswa telah memasuki tahap operasi formal. Siswa dapat memberikan alasan dengan menggunakan simbol atau gagasan, mampu memecahkan masalah dengan cara yang lebih baik (Sulasno, 2011).

Berdasarkan hasil wawancara dari beberapa narasumber guru SMP kelas VII dari tiga sekolah diperoleh kesimpulan sebagai berikut : 1) Pada umunya peserta didik kelas delapan SMP memiliki rasa ingin tahu yang cukup tinggi, masih suka berkelompok, sudah mulai susah di atur dan belum dapat berkonsentrasi penuh pada saat menerima pelajaran. Salah Bahwa siswa SMP kelas VIII pada umumnya mulai menginjak masa remaja dimana sudah mulai dapat berfikir secara formal. Dimana siswa sudah dapat menemukan konsep dari materi yang di berikan tanpa menggunakan bantuan alat peraga. Tetapi dapat memanfaatkan benda-benda yang ada di sekeliling siswa atau benda-benda nyata yang ada di kehidupan sehari-hari agar pembelajaran matematika lebih bermakna. (2) Dari narasumber guru, yakni guru-guru berpendapat bahwa siswa kelas VIII memiliki sikap yang berbeda-beda ada yang jika sulit mereka merasa malas da nada juga yang mempunyai keingintahuan yang tinggi, khususnya pada saat belajar materi baru. Jika pada awalnya mereka bingung, tetapi jika mereka sudah belajar dan sedikit mengerti mereka akan lebih ingin tahu. Akan tetapi jika materi yang di berikan sudah pernah di ajarkan mereka akan mengikuti. Hal terpenting adalah bagaimana guru mengontrol emosi ketika siswa terlihat malas dalam mengikuti pelajaran. Guru harus bisa membuat kegiatan belajar mengajar menyenangkan. Sehingga peserta tidak merasa bosan.

Berdasarkan hasil wawancara dari beberapa narasumber yang diperoleh kompetensi yang diinginkan oleh narasumber terhadap peserta didik yang berada pada tingkatan sekolah menengah pertama kelas VIII dapat disimpulkan sebagai berikut: 1) Dari segi akademik: Peserta didik sekolah menengah pertama kelas VIII diharapkan mampu untuk memahami seluruh konsep matematika yang berhubungan dengan kehidupan sehari-hari walaupun bahan ajar yang digunakan masih terbatas dan tidak hanya menggunakan satu sumber saja, namun siswa menengah pertama kelas VIII diharapkan mampu menguasai konsep pelajaran matematika 2) Dari segi sikap dan perilaku: Dapat mengaplikasikan matematika dalam kehidupan sehari-hari, Dapat berkonsentrasi penuh pada saat menerima pelajaran, Tidak berbicara dengan teman pada saat guru menjelaskan materi

Berdasarkan hasil wawancara tersebut tentu dapat mendukung pembelajaran dengan menggunakan berbasis LKS strategi metakognitif, sehingga kemampuan itu dapat dicapai. Berdasarkan pengamatan, karakter siswa kelas tujuh adalah sebagai berikut: Pada saat guru menjelaskan pelajarannya ada beberapa siswa yang tidak fokus pada pelajaran yang sedang berlangsung, Ketika pembelajaran berlangsung siswa tidak aktif dalam proses pembelajaran karena hanya mendengar penjelasan dari siswa guru tidak memiliki kemampuan yang baik dalam memecahkan masalah matematika ketika guru menjelaskan bahwa ada beberapa siswa yang berdiskusi dengan rekan- rekan mereka, yang membahas materi di luar pelajaran, para siswa seperti kelompok saat jam istirahat Karakter ini menunjukkan bahwa siswa bukanlah anak yang individualis.

Dalam mengembangkan bahan ajar instruksional, terdapat tiga sistem yang di gunakan seperti tatap muka, belajar secara mandiri dan belajar menggunkan media. Disini pendesain menggunakan sistem pembelajaran tatap muka, dengan bahan yang di kembangkan berupa LKS. Pada sistem pembelajaran tatap muka, pengajar bertindak sebagai sumber belajar utama dan menyajikan bahan instruksional yang di kompilasi. Antara pengajar dan bahan instruksional kompilasi harus saling berkaitan.

Proses yang harus di lakukan pertama kali dalam mengembangkan bahan ajar LKS adalah dengan melakukan analisis kebutuhan terhadap siswa untuk mengetahui kebutuhan di lapangan, kemudian pendesain menyusun strategi pembelajaran untuk mengatasi permasalahan-permasalahan yang ada saat melakukan analisis kebutuhan, kemudian pendesain merancang bahan instruksional berdasarkan strategi pembelajaran yang telah dibuat sebelumnya. Pendesain mendesain bahan ajar sesuai dengan materi pembelajaran Matematika Sekolah Pertama kelas VII. Bahan ajar ini di susun sedemikian rupa sehingga mempermudah siswa dalam memahami materi tersebut. Setelah mendesain bahan ajar, maka di lanjutkan dengan membuatinstrumen yang digunakan untuk penilaian bahan ajar yang dibuat sebagai alat ukur kualitas bahan ajar yang didesain. Aspek yang di gunakan meliputi sapek bidang studi, aspek penyajian dan aspek desain grafis.

Selanjutnya pendesain membuat instrument evaluasi formatif. Instrumen ini meliputi kisi-kisi soal, soal-soal dan latihan, instrumen-instrumen ini disusun untuk mengetahui tingkat pencapaian tujuan instruksional setelah menggunakan bahan ajar berupa LKS matematika dengan strategi metakognitif 
pada Sekolah Menengah Pertama kelas VII. Untuk melakukan uju validasi di butuhkan beberapa ahli pakar, seperti pakar bahasa yang di lakukan oleh dosen bahasa, pakar materi yang di lakukan oleh ahli matematika dan pakar media yang di lakukan oleh dosen yang ahli di bidang desain grafis. perbaikan akan di lakukan beberapa kali sehingga dapat bermanfaat sekali dalam perbaikan bahan pelajaran yang di tinjau berdasarkan muatan isi, desain buku meupun penyampaiannya.

Berikut merupakan hasil evaluasi guna memenuhi kegiatan evaluasi formatif yang berupa saran dan komentar: saran dan komentar yang diberikan Ahli materi bahan instruksional adalah: 1) Untuk memperbanyak latihan soal, 2) Materi sudah sesuai dengan TIU dan TIK yang dikembangkan, 3) Pemberian keterangan pada gambar lebih di perjelas

Untuk saran dan komentar yang diberikan oleh Ahli bahasa bahan instruksional adalah: 1) Untuk memperhatikan kesalahan pengetikan, 2) Memperhatikan rata kanan dan kiri, 3) Perbaiki penggunaan bahasa (kata hubung) seperti di. Saran dan komentar yang diberikan oleh ahli media dosen adalah: Memperhatikan degadrasi warna latar LKS dengan tulisan

Setelah melihat penilaian yang diberikan oleh para ahli dan dosen pembimbing, penulis dapat mengemukakan keunggulan dari desain ini, antara lain: 1) Adanya keterkaitan antara materi yang satu dengan yang lain sehingga dapat mempermudah peserta didik dalam mempelajarinya 2) Pemecahan masalah yang tertera dalam bahan ajar ini berhubungan dengan kehidupan sehari-hari yang diharapkan dapat membuat pola pikir peserta didik lebih baik. 3) Desain bahan ajar yang cukup menarik peserta didik untuk belajar matematika. 4) Terdapat soal cerita pada setiap subbab yang membantu peserta didik mengembangkan pola pikirnya dalam mengaplikasikan matematika ke dalam kehidupan sehari-hari. 5) Terdapat soal prasyarat yang membantu peserta didik mengingat kembali materi yang sudah dipelajari sebelumnya

\section{SIMPULAN DAN SARAN}

Pengembangan strategi metakognitif berbasis LKS berbasis matematika dapat memberi kesempatan kepada siswa untuk membangun pengetahuan dengan terlibat dalam aktivitas berpikir aktif. Melalui strategi pembelajaran metakognitif, pemecahan masalah matematis dapat diarahkan untuk mengembangkan ketrampilan siswa seperti: membangun pengetahuan matematika baru, memecahkan masalah dalam berbagai konteks yang berkaitan dengan matematika, menerapkan strategi yang diperlukan, dan merenungkan proses pemecahan masalah secara matematis. Hasil analisis kebutuhan adalah siswa kelas VII menjadi subjek penelitian LKS berdasarkan strategi metakognitif.
Siswa yang berusia 11-15 tahun berpikiran lengkap, berpikir proporsional, kemampuan untuk mengatasi hipotesis. Pada usia ini siswa telah memasuki tahap operasi formal. Kursus ini dapat mendukung pembelajaran dengan menggunakan strategi metakognitif berbasis LKS, sehingga kemampuan siswa dapat tercapai.

\section{UCAPAN TERIMA KASIH}

Apresiasi dan terima kasih kepada Direktorat Riset dan Pengabdian Masyarakat, Dirjen Penguatan Riset dan Pengembangan, Kementerian Riset, Teknologi dan Pendidikan Tinggi yang telah membiayai kegiatan penelitian Dosen Pemula (PDP) Tahun 2017 dengan judul: "Pengembangan LKS Pemecahan Masalah Matematika Program Bilingual Berbasis Strategi Metakognitif untuk Smp Kelas VII Semester Ganjil ". Terima kasih juga kepada Lembaga Penelitian dan Pengabdian Masyarakat Universitas Indraprasta PGRI Jakarta yang telah membantu kegiatan penelitian ini melalui Kontrak Penelitian No. 0428/K3/KM/2017, Tanggal 24 Mei 2017. Dan No.0583/SKP.LT/LPPM/UNINDRA/VI/2017, tanggal 05 Juni 2017.

\section{REFERENSI}

[1] Iskandarwassid dan Dadang S. (2008). Strategi Pembelajaran Bahasa. Bandung: Remaja Rosdakarya

[2] Kellough, R. D. (1994). Sebuah Panduan Sumber Pengajaran: K-12. New York: Macmilan Publising Company.

[3] Majid, A. (2012). Strategi Pembelajaran, Bandung: PT Remaja Rosdakarya

[4] NCTM. (2015). "Prinsip dan Standar untuk Sekolah Matematika"

http://www.nctm.org/uploadedFiles/Math Standards $\angle 12752$ exec pssm.pdf, diakses Tanggal 10 Desember 2015

[5] Pannen. (1997). Pendekatan Program Terapan, Mengajar di Perguruan Tinggi. Jakarta: Direktorat Jenderal Perguruan Tinggi Departemen Pendidikan dan Kebudayaan

[6] Prastowo, A. (2011). Panduan Kreatif Membuat Bahan Ajar Inovatif. Yogyakarta: Diva Tekan.

[7] Sprinthal, N. A. 1. (1992). Pendidikan Psikologi: Pendekatan Pembangunan. Tokyo: Craw Hall.

[8] Trianto. (2012). Model Pembelajaran Terpadu. Jakarta: Bumi Aksara 